\title{
DO RESEARCH! FORSCHEN!
}

\section{$\nearrow$ CHRISTOPH KALTENBRUNNER}

In hindsight, every result of work done in artistic research is subject to its own special logic a logic that arises from the actors, discussions, influences, discoveries and much more, which allows the research process to probe into uncharted territory.

The aim of this research proposal was to observe and discuss traditional joints in timber construction that do not require metal connectors. This initially required adequate problem analysis and anamnesis, which marked out the path into the research field; in a further step, the accumulated knowledge was transcribed into 'utopian' wood connections.

In contrast to quantifiable scientific research, artistic research can be based on intuition, feeling, experimentation, aesthetics - on sensual and physical perception. This kind of research opens up an interdisciplinary realm. Within this space of reciprocal relationships, the research work presented here analyzed and reflected upon, among other things, the historical construction of roof trusses as well as wooden ships, and on the basis of these findings, the forestry of that time was compared with that of today.

Nowadays, the straight growth of a tree is preferred both economically and generally. For shipbuilding in the past, sometimes one would deliberately choose or even cultivate 'crooks', i.e. woods with a special shape, which were built into a ship's structure at exposed points of the force flow. The curvilinear growth of the component would guarantee optimum material utilization for transferring loads. This kind of empirical use of material lies far from the current convention based on economics, automation and optimization.

In the approach of the empirical design process used during the research period, the tree was not perceived as a 'board supplier', but
Rückblickend betrachtet unterliegt jedes Ergebnis einer künstlerischen Forschung seiner speziellen Logik. Eine Logik, die sich aus den Akteur*innen, Diskussionen, Einflüssen, Entdeckungen und vielem mehr ergibt und den Forschungsprozess in ungeahnte Bereiche vordringen lässt.

Beobachtet und diskutiert werden sollten laut Forschungsantrag traditionelle Verbindungen im Holzbau, die ohne Metallverbinder auskommen. Dazu bedurfte es zunächst einer adäquaten Problemanalyse und Anamnese, die den Weg in das Forschungsgebiet absteckten; in einem weiteren Schritt wurde das gesammelte Wissen in ,utopische' Holzverbindungen transkribiert.

Im Gegenteil zur messbaren wissenschaftlichen Forschung kann sich die künstlerische Forschung auf Intuition, Gefühl, Experiment, Ästhetik - auf sinnliche und körperliche Wahrnehmung stützen. Diese Art Forschung öffnet einen interdisziplinären Raum. In diesem Raum wechselseitiger Beziehungen wurden in der hier vorgestellten Forschungsarbeit unter anderem der historische Dachstuhl- sowie der Holzschiffsbau analysiert bzw. reflektiert, und anhand dieser Erkenntnisse wurde die Forstwirtschaft von damals mit der gegenwärtigen verglichen.

Gilt heute der gerade Wuchs eines Baumes als wirtschaftlich und wünschenswert, suchte oder züchtete man für den Schiffsbau in der Vergangenheit bewusst ,Krummlinge', also Hölzer mit besonderer Form, die an exponierten Stellen des Kraftflusses in die Schiffskonstruktion eingebaut wurden. Der krumme Wuchs des Bauteils garantierte eine optimale Materialnutzung für den Lastabtrag. Diese Art empirischer Nutzung von Material liegt der gegenwärtigen Vorstellung von Wirtschaftlichkeit, Automatisierung und Optimierung fern.

In Annäherung an diesen empirischen Designprozess wurde im Laufe der Forschungsdauer der Baum nicht als ,Brettlieferant' wahrgenommen, sondern in seinem Ganzen betrachtet, gedacht und genutzt. Die daraus entwickelten Astgabel-Strukturen (Branch Formations) 


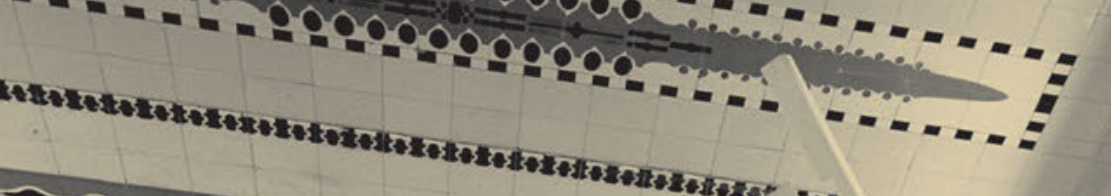

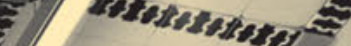

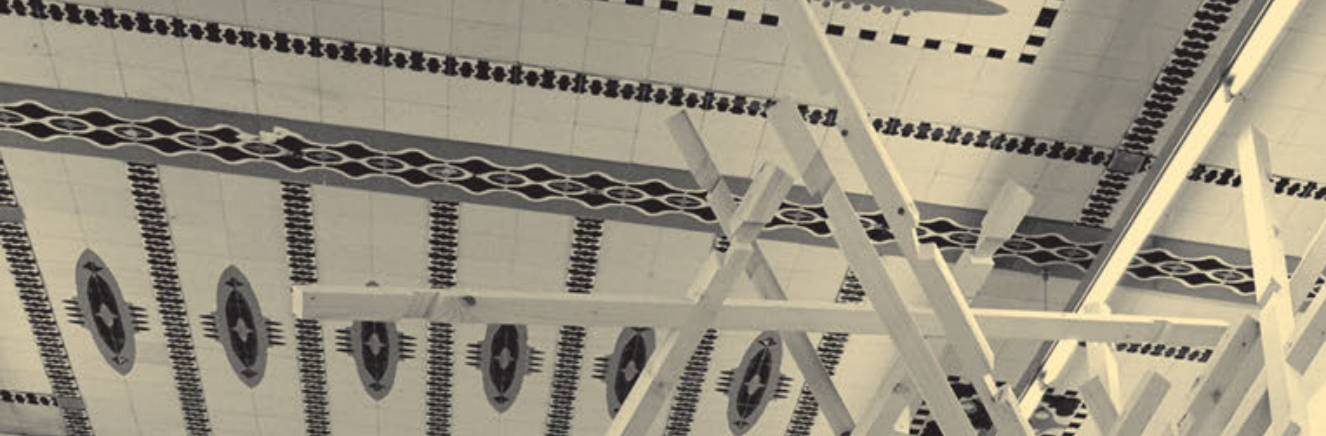

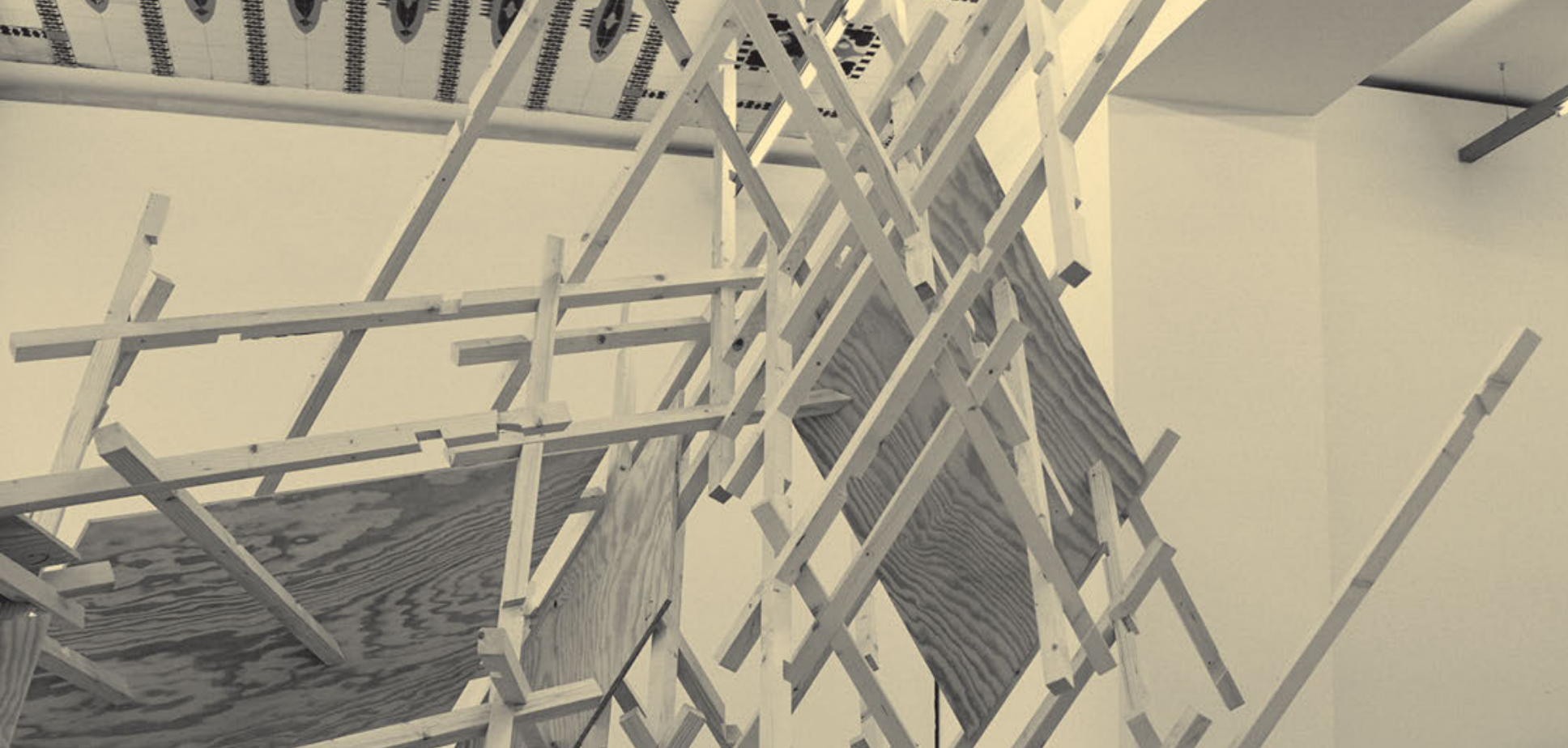


was rather considered, thought about, and used in its entirety. The resulting branch structures (Branch Formations) not only deal with the optimal coupling of tetrahedron modules and their particular idiosyncrasies when being used as building components, but they also embody a reflection of a sustainable utilization of the material wood.

Forestry will undergo an essential restructuring over the coming decades, because global warming is changing the cultivation of timber in particular. Due to the presumably increasing average annual temperatures, the tree line will move to higher altitudes - the optimal habitat of timbers (such as spruce or fir) will become out of reach for economic harvesting. Today, branches are processed into wood chips, if at all, and the unusable remainder is left as biomass in the forest.

The focus of this research work was therefore directed towards hardwoods. Initial investigations of hornbeam branch forks showed that they could be used as a suitable components of tectonic structures, not only due to their angular fidelity between the main and secondary shoots, but also because of their structural consolidation by means of material accretion at the branch node - a hypothesis that was investigated and experimentally explored through a 'trial and error' method. Each of the harvested branch forks was tested for its properties and positioned as a 3D scan in a digital model. The assembly process was informed by a specially developed software algorithm to facilitate a spatially closed support system that could evolve. The connection points of the forks were interlocked in a form-fitting way, and by joining several branch forks, a self-contained tectonic structure was developed.

Initial experiments on a reduced scale were carried out using a robot from the University of Arts Linz in order to apply the knowledge generated from the previous studies to developing special tools for branch fork processing. These were subsequently carried forward for the large-scale implementation of branch fork connections, together with the Angewandte Robotics Lab. beschäftigen sich nicht nur mit der optimalen Kopplung von Tetraedern und deren besonderen Eigenschaften als Bauteil, sondern sind auch für sich ein Abbild einer nachhaltigen Nutzung des Werkstoffs Holz.

Die Forstwirtschaft wird in den nächsten Jahrzehnten eine essenzielle Umstrukturierung erfahren, denn speziell die Klimaerwärmung verändert den Anbau von Nutzholz. Wegen der vermutlich steigenden Jahresdurchschnittstemperaturen wandert die Baumgrenze in höhere Lagen - der optimale Lebensraum von Bauholz (wie Fichte oder Tanne) wird die Gebiete des wirtschaftlichen Erntens von Nutzholz verlassen. Äste werden heute, wenn überhaupt, als Hackschnitzel aufgearbeitet, der nicht nutzbare Rest bleibt als Biomasse im Wald zurück.

Der Fokus der Forschungsarbeit wurde daher auf das Laubholz gerichtet. Erste Untersuchungen von Hainbuchen-Astgabeln zeigten, dass diese nicht nur durch ihre Winkeltreue von Haupt- zu Nebentrieb im Wuchsalter, sondern auch durch ihre Verfestigung mit Hilfe von Materialzuwachs am Astknoten ein geeignetes Bauteil von tektonischen Strukturen sein könnten eine Hypothese, die nach dem Prinzip ,trial and error' untersucht bzw. experimentell erforscht wurde. Jede der geernteten Astgabeln wurde auf ihre Eigenschaften hin geprüft und durch einen speziell entwickelten Software-Algorithmus als digitaler 3D-Scan in Lage gebracht, sodass sich ein räumlich geschlossenes Tragsystem bildete. Die Verbindungspunkte der Gabeln wurden räumlich formschlüssig verzahnt, und durch Fügen von mehreren Astgabeln entwickelte sich ein in sich geschlossenes tektonisches Gebilde.

Erste Versuche im verkleinerten Maßstab fanden mit einem Roboter der Kunstuniversität Linz statt, um mit dem aus den Experimenten generierten Wissen spezielle Werkzeuge für die Astgabel-Verarbeitung zu entwickeln. Diese wurden in weiterer Folge für die großmaßstäbliche Umsetzung der Astgabel-Verbindungen mit dem Angewandte Robotics Lab weiter getragen.

Der Diskurs endete nicht bei Astgabeln - das Fügen von Holz wurde und wird weltweit praktiziert. Unter anderem entstanden während einer Japan-Exkursion erste Ideenskizzen zu Holzstrukturen mit Steckverbindungen, die anschließend bei einem mehrtägigen Workshop an der Universität für angewandte Kunst Wien unter Leitung von Jun Sato (University of Tokyo) in Modellen einer Kigumi-Konstruktion weiter entwickelt 


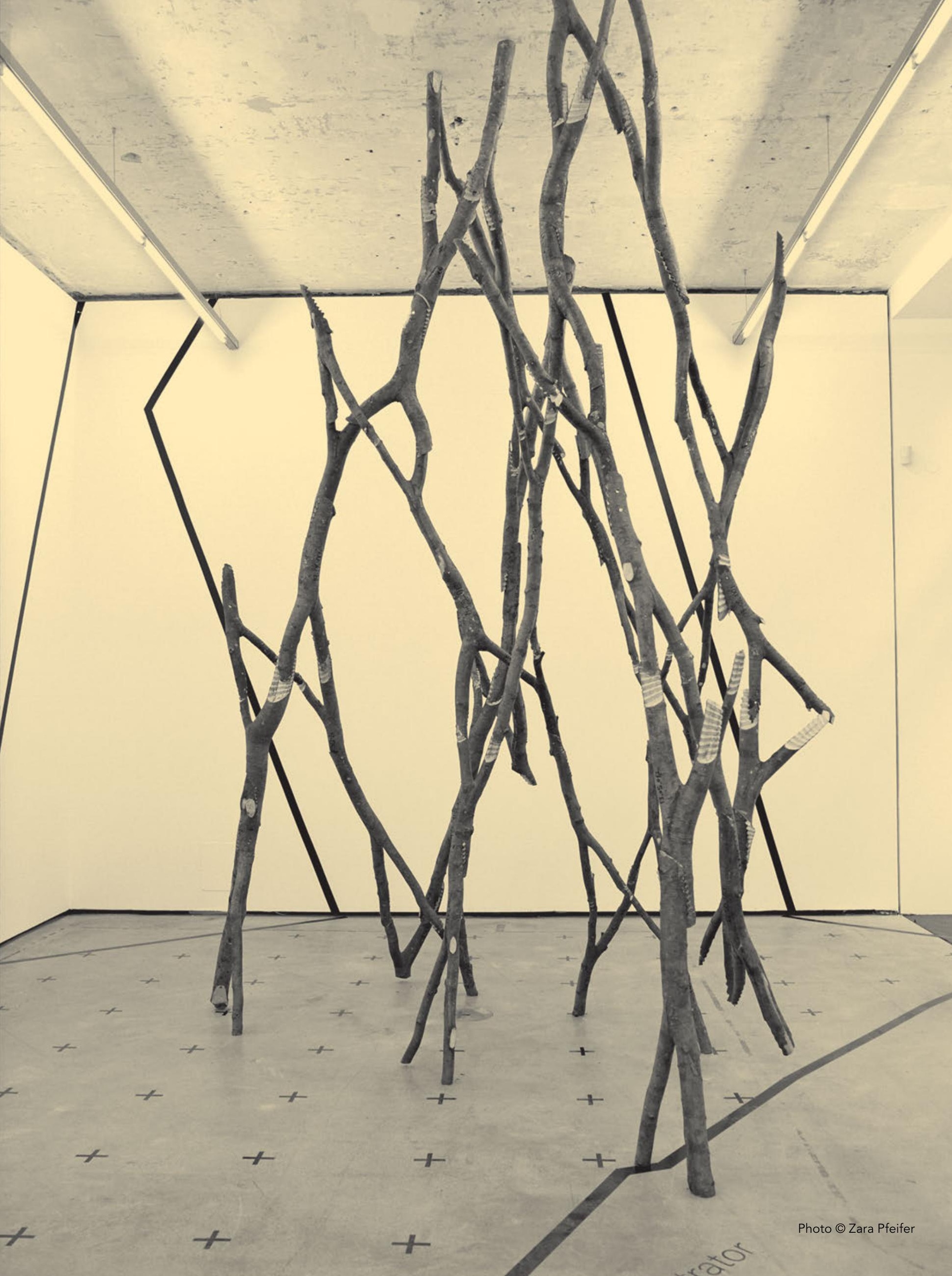


The discourse mentioned at the beginning did not end exclusively with branch forks - the culture of joining wood as it is practiced worldwide persisted as a key interest. Initial sketches of ideas for wooden structures with interlocking push-fit connections started to appear during a field trip to Japan. Subsequently, these concepts were further developed in models of a Kigumi structure during a workshop led by Jun Sato (University of Tokyo) that took place over several days at the University of Applied Arts Vienna. These complex frameworks of sticks with their sophisticated knots had to be implemented in wood.

The Landesberufsschule Murau (Styria) propelled the success of this experiment. Thanks to their interest and generous support, it was possible to experimentally develop complex Kigumi knots with the school's own CNC joinery machine. Among other things, the research team was able to present the complex beam structures made of square timber profiles to an international audience as part of World Wood Day 2019, hosted by the Open Air Museum in Stübing (Styria).

Looking back, the outcomes of this research project appear to be obvious results. But they were only conceivable and thus realizable through artistic research and within an interdisciplinary space.

In doing so, this research team with an affinity for engineering has succeeded in transcribing historical knowledge of timber construction into the present, without being traditionalist. wurden. Diese komplexen Stabstrukturen mit ihren raffinierten Knoten galt es in Holz umzusetzen.

Für das Gelingen dieses Experiments trug wesentlich die Landesberufsschule Murau (Steiermark) bei. Dank ihrem Interesse und der freundlichen Unterstützung war ein experimentelles Entwickeln von komplexen Kigumi-Knoten an der schuleigenen CNC-Abbundmaschine möglich. Die komplexen Stabwerke aus Vierkantstäben konnte das Forschungsteam unter anderem am World Wood Day 2019 im Freilichtmuseum Stübing (Steiermark) einem internationalen Publikum präsentieren.

Rückblickend betrachtet scheinen die Ergebnisse dieses Forschungsvorhabens offensichtlich auf dem Tisch zu liegen. Doch sie waren erst durch die künstlerische Forschung und den interdisziplinären Raum denk- und somit machbar.

Dabei ist es dem ingenieuraffinen Forschungsteam mit seinen Arbeiten gelungen, historisches Wissen des Holzbaus in die Gegenwart zu transkribieren, ohne dabei tradiert-anbiedernd zu sein. 


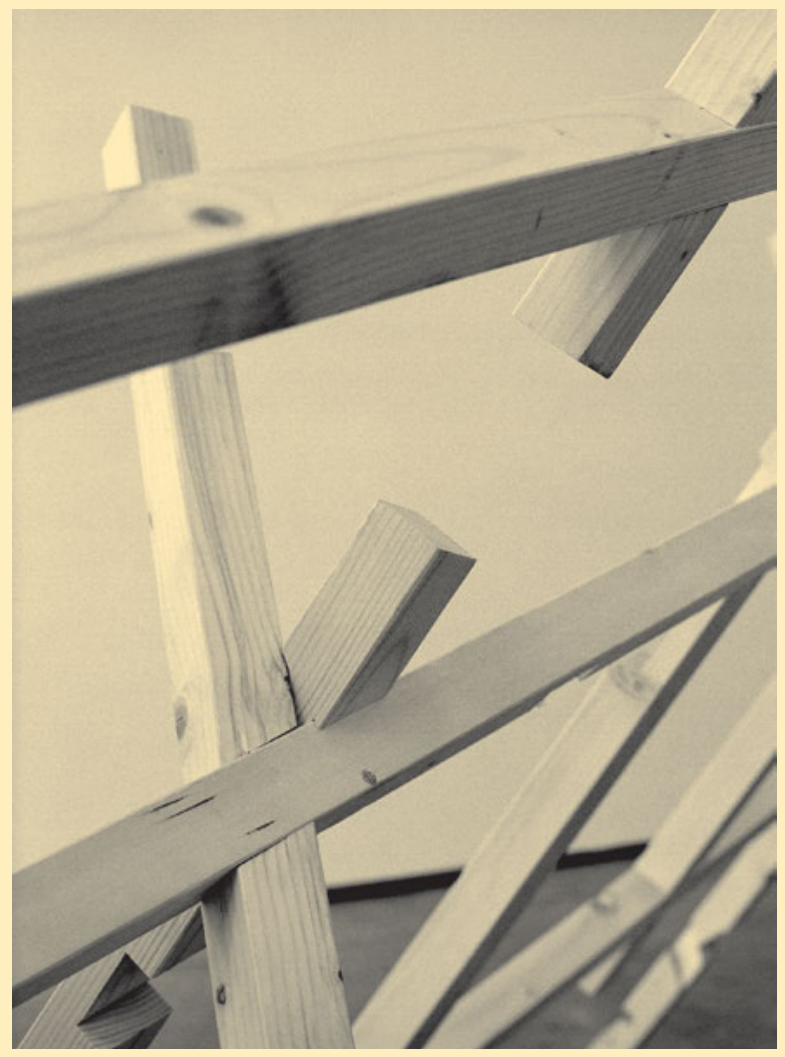

$\Delta$ Details of the second Interlocking Spaces installation (top) and the Branch Formations demonstrator (right) at the Conceptual Joining show at AIL 2019.

Photos @ Zara Pfeifer

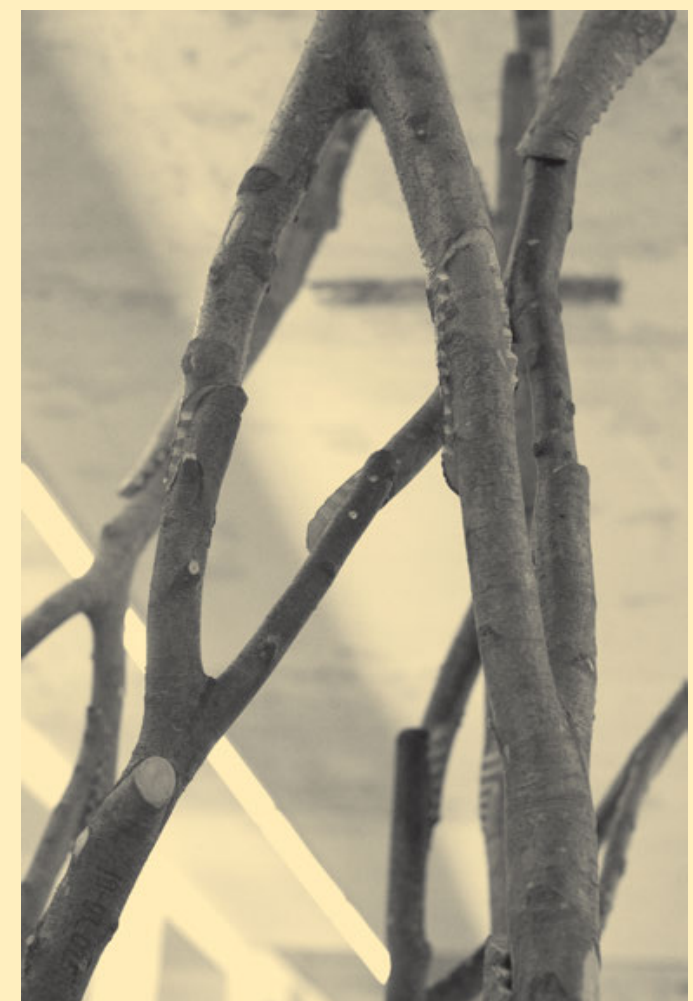


